machines, in which colour now contributes to safety and eye comfort as well as to cleanliness and decoration in the ordinary sense.

The author, recognizing these things and clearly being fascinated by the subject, has sought to present its enormous sweep in a series of cameos in twenty chapters arranged in six groups under the following headings : 1 , foundations of colour-light, matter and sight; 2, colours by Nature and how produced; 3 , colours by man and how produced; 4, guides to use of colour-colour terms and names, harmony and discord in colour combinations ; 5, colour for everyono-apparel and building; and 6, relation of colour to man's progress--special uses of colour.

In the result the substance of each chapter is a prézis, or in some casas a partial abstract, of the reference books listed at the end of each chapter. At this point it is only fair to repeat some of the author's introductory words, namely: "This book is not intended to be a guide for any science, trade or profession, but a source of pleasure and profit for the average man, woman and child . . . to present a variety of facts, thiories, experiences and observations about colour that will be interesting and useful. ...."

There remains the question of accuracy. Are the factual statements which the author has made correct? On this I have to record that the chapter entitled "Paints" shows some confusion of thought, though comparatively little editing would have removed any cause for complaint. After all, it is not reasonable to be able to describe all the pigments, white and coloured, and the principles of paint manufacture, in nine not very closely printed pages. On the other hand, I was intrigued to read among a multitude of 'titbits' about a great variety of subjects that turkey flesh should have no purple tinge, as this marks an old bird-I shall examine my next turkey with added interest.

L. A. JORDAN

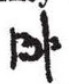

\section{TREATISE ON ZOOLOGY}

Traité de zoologie

Anatumie, systématique, biologie. Publié sous la direction de Prof. Pierre-P. Grassé. Tome 11 : Échinodermes, stomocordés, procordés. Par P. Brien, M. Caullery, L. Cuénot, A. Daleq, C. Dawydoff, P. Drach, H. Harant, G. W. Tatot. Pp. viii +1,078. (Paris: Masson et C Of Lof 8.) 3,800 francs.

TO older zoolorist the litle "Traité de zoologie" will recal to extensive work published by Prof. Ed mond Pefiar, the first volume of which appeared in 1893 . Ut held its place on the bookshelf for many ye. 9 and even now some parts bear reference; but obviously in fifty years a vast amount of water has flowed under the bridge. The present work has a similar format and 'get up', but has a striking difference in that it has ninety-three collaborators from France, Belgium, Switzerland, Algiers, Egypt and Morocco, united under the direction of Pierre-P. Grassé, professor at the Sorbonne. This new treatise is planned to extend to seventeen volumes, each of which will consist of about $1,000-1,200$ pages and will be fully illustrated.

The publication of such a large work has dangers not encountered in issuing a single large volume, or a small number of volumes. It may spread over such a long period that the first volumes are quite out of date before the last ones appear, so that it does not form a usable whole; or it may suffer the fate of Lankester's "Treatise", Délage et Hérouard, or Kükenthal und Krumbach, which were never completed. It is to be hoped that the present commendable work will avoid these dangers, and the fact that a large number of authors are collaborating may help. Four more volumes are scheduled to appear in 1949 , and at least three in 1950; and if this rate is maintained the work should be completed in little more than four years, a not unreasonable time. The large number of contributors should also make it possible for each section to be up to date and authoritative, for it is obviously impossible for one or even a small group of authors to cover adequately the vast field of modern zoology.

The volume at present under review, while it is number 11 in the series, is actually the first to appear, and so may be taken as a sample of thase to follow. It contains 1,078 pages with 993 figures, 11 of which are in half-tone, 11 reinforced by colour, and the remainder in line block; they are deserving of high praise. The volume deals with the systematics, anatomy and biology of the Echinodermata, Stomochorda (Hemichordata) and Prochorda (Tunicata and Cephalochordata). Each section is provided with its own bibliography, which varies in extent according to the availability of recent bibliographies. The principal contributors are Profs. L. Cuénot (Nancy), C. Dawydoff (Paris), P. Brien (Brussels) and P. Drach (Sorbonne). The group Stomochorda is set up because the pharyngeal diverticulum lies near the mouth, and it is held that this is a structure sui generis and is not strictly homologous with the notochord of the true chordate. The structure itself is referred to as a stomochord (stomocord) to emphasize this distinction. The recent researches of O. M. B. Bulman and Kozlowski, taken fully into account, show that the Graptolites are more closely allied to the Pterobranchia than they are to the groups with which they have been associated previously, the Sertularian Hydrozoa or the Bryozoa, and consequently they have been included as a class of the Stomochorda. Cuénot has a discussion (pp. 359-361) of the relationship of the dipleurula of the Echinoderms to the tornaria of the Enteropneusts, and of the basic trimerism of the former phylum as indicated by the development of the colom. This, read in conjunction with the fuller discussion by Dawydoff of the Stomochorda and their affinities (pp. 511-532), shows clearly that both authors recognize an ancestral relationship between the Echinodermata and the Stomochorda, and, of course, the latter are clearly related to the Prochordata. Thus the three groups are logically included in the same volume.

On the whole the book is excellently printed and illustrated, and the paper is very good. A detailed index is furnished and a very full table of contents which is placed right at the end of the volume. It is a pity that a number of slips have been allowed to pass uncorrected, ,for example: p. 297, deutoplosme for deutoplasme; p. 362, Mac Millan for Macmillan; p. 488, McIntosch for McIntosh; p. 452, Bulloc for Bullock; p. 947, fig. $407, e$ in the diagram is $\mathrm{Fe}$ in the legend; and p. 494, fig. $408, v s$ in the diagram is vis in the legend, etc. Apart from these, the authors, editor and publishers are to be congratulated on initiating a series of volumes that should prove most useful to all zoologists, and we wish their venture every success.

C. H. O'DoNOGHUE 